\title{
Production of Rabbit Antibodies against Purified Glucose Oxidase
}

\author{
Muhammad Anjum Zia ${ }^{1 *}$, Qurat-ul-Ain ${ }^{1}$, Tehreema Iftikhar ${ }^{2}$, Rao Zahid Abbas ${ }^{3}$ and \\ Khalil-ur-Rahman ${ }^{1}$ \\ ${ }^{I}$ Enzyme Biotechnology Lab; Department of Chemistry and Biochemistry; University of Agriculture; Faisalabad - \\ 38040, Pakistan. ${ }^{2}$ Department of Botany; GC University; Faisalabad - Pakistan. ${ }^{3}$ Department of Parasitology; \\ University of Agriculture; Faisalabad-38040, Pakistan
}

\begin{abstract}
Glucose oxidase is an active oxygen species generating enzyme produced from Aspergillus niger grown in submerged fermentation. Disintegration of the mycelium resulted in high glucose oxidase activity that was subjected to ammonium sulfate precipitation at $60-85 \%$ saturation rates that resulted to $6.14 \mathrm{U} \mathrm{mg}^{-1}$ specific activity. Purification of enzyme by anion exchange column (DEAE-Cellulose) resulted into $22.53 \mathrm{U} \mathrm{mg}^{-1}$ specific activity and 10.27 fold purification. This was applied to sephadex $G-200$ column for gel filtration chromatography. It was observed that enzyme achieved $59.37 \mathrm{U} \mathrm{mg}^{-1}$ of specific activity with 27.08 fold purity and $64.36 \%$ recovery. Purified glucose oxidase was injected into rabbits through intravenous route, to raise the glucose oxidase antibodies. After 30 days incubation period, the rabbits were slaughtered and serum was separated from blood. The antibodies were isolated by ammonium sulfate precipitation and confirmed by agar gel precipitation test. This could be a convenient and low cost alternate assay for the estimation of glucose oxidase in biological fluids. Moreover, such antibodies against the said enzyme could be used in various therapeutic and diagnostic applications.
\end{abstract}

Key words: Glucose oxidase, A. niger, Antibodies, Rabbits

\section{INTRODUCTION}

Glucose oxidase (E.C 1.1.3.4) is an active oxygen species generating enzyme from the fungus Aspergillus niger. Glucose oxidase is an oxidoreductase; it is also called as glucose aerodehydrogenase (Witteveen et al. 1992). Glucose oxidase is a glycoprotein that catalyzes the oxidation of beta-D-glucose to D-gluconic acid and hydrogen peroxide, the molecular oxygen is consumed in the process (Wu et al. 1995). Filamentous fungi are of considerable biotechnological importance as producers of broad range of metabolites end enzymes In general, many enzymes of industrial interest are obtained from the fungal cultures (Luque et al. 2004).

Glucose oxidase has several applications, especially in food and clinical analysis. The increasing number of potential uses of this enzyme in health/clinical sciences and biosensors, have made it as an ideal diagnostic tool (Banker et al. 2009). Glucose oxidase is used in food industry for the removal of glucose from the powdered eggs, as a source of hydrogen peroxide in food preservation. It is a source for gluconic acid production and in the production of beer and soft drinks, where it serves as an antioxidant (Scott 1984). In health/medical industries, glucose oxidase is used for the quantitative determination

*Author for correspondence: scientistuaf@yahoo.com 
of D-glucose in biological samples and fermentation products. Glucose oxidase as an immunogen is used to prepare the antibodies for the detection of antigens in histological and cytological preparations and for the detection and quantitation of solid phase antigens in techniques such as ELISA, immunoblotting and dot blotting (Wilson and Turner 1992). The aim of this work was to study the purification of glucose oxidase from Aspergillus niger and its application to produce glucose oxidase antibodies in rabbits.

\section{MATERIALS AND METHODS}

\section{Microorganism}

Pure culture of fungus Aspergillus niger was procured from the Department of Chemistry and Biochemistry, University of Agriculture Faisalabad and was raised on potato-dextrose-agar slants, by incubated aerobically at $30^{\circ} \mathrm{C}$. The spores of A. niger were prepared in Vogel's medium containing (g $\left.100 \mathrm{ml}^{-1}\right) \quad \mathrm{KH}_{2} \mathrm{PO}_{4} \quad 0.5$, $\mathrm{NH}_{2} \mathrm{NO}_{3} 0.2,\left(\mathrm{NH}_{4}\right)_{2} \mathrm{SO}_{4} 0.4, \mathrm{MgSO}_{4} .7 \mathrm{H}_{2} \mathrm{O} \quad 0.02$, peptone 0.1 , trisodium citrate 0.5 , yeast extract 0.2 , glucose $50 \% \mathrm{w} / \mathrm{v}(\mathrm{pH} 5.5)$, in $250 \mathrm{~mL}$ Erlenmeyer flask with working volume of $50 \mathrm{~mL}$ iand incubated at $30^{\circ} \mathrm{C}$ and $120 \mathrm{rpm}$ (Haq et al., 2001). All the chemicals/reagents used were purchased from Sigma Chemical Inc.

\section{Production of glucose oxidase}

The strain was used for growth in submerged fermentation in order to produce the glucose oxidase activity. After $36 \mathrm{~h}$, the mycelia were disrupted in a homogenizer by a glass cell homogenizer for 10 minutes and resulting suspension was subjected to centrifugation at speed $10,000 \mathrm{rpm}$ for $15 \mathrm{~min}$ at $0^{\circ} \mathrm{C}$ in order to disrupt/remove the cell membranes (Zia et al. 2010). Intracellular glucose oxidase activity was determined by enzyme assay as described by Worthington (1988). Biuret method was used for the determination of concentration of protein using bovine serum albumin as standard (Gornall et al. 1949).

\section{Purification of glucose oxidase}

The purification of intracellular glucose oxidase enzyme was carried out by ammonium sulfate precipitation, ion exchange and gel filtration chromatography. Solid ammonium sulfate was added to the crude extract until it was $60-85 \%$ saturated. Later, the desired enzyme was desalted by dialysis. A column of DEAE-(diethyl amino ethyl) cellulose was prepared by the method of Sukhacheva et al. (2004). The desalted enzyme sample of $1.5 \mathrm{ml}$ was poured on the surface of column $(2 \times 14 \mathrm{~cm})$. The elution of sample was carried out with $0.1 \mathrm{M}$ phosphate buffer $(\mathrm{pH}$ 6.0).The drop rate of eluted sample was kept constant and 100 fractions of $2.0 \mathrm{~mL}$ each were collected.

A column of Sephadex G-200 $(2 \times 12 \mathrm{~cm})$ was prepared by the method described by Sukhacheva et al. (2004). The sample having the maximum specific activity eluted with phosphate buffer during ion exchange chromatography was applied and allowed to penetrate in packed column. Elution was carried out by $0.1 \mathrm{M}$ phosphate buffer (pH 6.0) at a constant drop rate. A total of 50 fractions of $2.0 \mathrm{~mL}$ each were collected which were subjected to enzyme assay and protein estimation as discussed above. The purity of the enzyme was verified by SDS-PAGE (Laemmli, 1970).

\section{Production of rabbit anti-glucose oxidase antibodies}

The rabbit glucose oxidase antibodies were produced by inoculating the purified glucose oxidase as antigen in rabbits. Six animals were selected and divided into two groups, each having three animals, named group $\mathrm{A}$ as control and group B as an experimental. The purified GOX $(18.94 \mathrm{U} / \mathrm{mL})$ was injected in healthy albino rabbit weighing $2-3 \mathrm{~kg}$ for the production of antibodies. The animal received subcutaneously $0.5 \mathrm{~mL}$ of 0.6 $\mathrm{g} \mathrm{l}^{-1}$ antigen dissolved in $0.02 \mathrm{~mol} \mathrm{l}^{-1}$ sodium phosphate buffer, $\mathrm{pH}$ 7.2. Booster doses of $0.3 \mathrm{~g} \mathrm{l}^{-1}$ antigen were administrated weekly for three weeks after resting the animal for 15 days. After each booster dose, blood was collected from the neck vein. Rabbits were slaughtered after 30 days of the last inoculation. The blood from both rabbits was collected in sterilized flasks and allowed to clot in slanting position. Then it was kept in refrigerator overnight and on the next day, the sera were oozed out from the clot and stored at $4{ }^{\circ} \mathrm{C}$ till its use (Wijewardena 1992).

\section{Confirmation/determination of glucose oxidase antibodies}

The rabbit glucose oxidase antibodies were confirmed by agar gel precipitation test (AGPT)/agar gel immuno-diffusion test (AGID) as 
described by Hudson and Hay (1980). Agar plates having the wells of equal size were prepared. The sample of rabbit-glucose oxidase antibodies was placed in each peripheral well, as equal amount of antigen was placed in the central well. These plates were placed in refrigerator up to the development of precipitation lines). A sample of $100 \mu \mathrm{l}$ of rabbit glucose oxidase antibodies was placed in each peripheral well and as $100 \mu \mathrm{l}$ of antigen was taken in the central well. Then these plates were placed in refrigerator up to the development of precipitation lines.

\section{RESULTS AND DISCUSSION}

Figure 4 - SDS-PAGE showing pure GOX was used as the antigen for the production of glucose oxidase antibodies in rabbit. The activity and specific activity of crude enzyme was $12.195 \mathrm{U}$ $\mathrm{ml}^{-1}$ and $2.192 \mathrm{U} \mathrm{mg}^{-1}$, respectively having 5.562 $\mathrm{mg} \mathrm{ml}{ }^{-1}$ of protein contents. Although several organisms have been reported to produce glucose oxidase, however, A. niger is the main organism used for industrial production (Khattab and Bazaraa, 2005). An amount of $2 \%$ (w/v) CSL used in liquid fermentation was inoculated with $5.0 \mathrm{ml}$ of homogenous spore suspension containing $10^{7}$ spores $\mathrm{ml}^{-1}$ in flasks (in triplicate). The culture filtrates were harvested after fermentation period of $36 \mathrm{~h}$.

\section{Purification of glucose oxidase}

To purify the desired enzyme, the crude extracts from CSL were subjected to $60-85 \%$ saturation with $\left(\mathrm{NH}_{4}\right)_{2} \mathrm{SO}_{4}$ to remove unwanted proteins. This is the most commonly used reagent for salting out of proteins because its high solubility permits the achievement of solution with high ionic strength. Various precipitation techniques have been used to isolate glucose oxidase, including ammonium sulfate, uranyl acetate and copper sulfate (Kalisz et al. 1991). The fraction of $60 \%$ supernatant and sediments showed the activity of 12.313 and $18.82 \mathrm{U} \mathrm{ml}^{-1}$, respectively. The $85 \%$ supernatant and sediments showed the activity of 14.38 and $20.74 \mathrm{U} \mathrm{ml}^{-1}$, respectively. Desalting was carried out by dialysis against the distilled water. Desalting is the phenomenon to remove the contaminating salt present in the sediments, resulting to increase the enzyme activity (Shin et al. 1993). Desalted sample showed the activity and specific activity of 12.41 $\mathrm{U} \mathrm{ml}^{-1}$ and $6.14 \mathrm{U} \mathrm{mg}^{-1}$, respectively. The results are shown in Figure 1.

The desalted enzyme was subjected to DEAECellulose column for ion exchange chromatography. Ion exchange cellulose is preferred because the fine particle size and high density of the microgranular cellulose that result in higher resolution (Jakoby 1971; Zia et al. 2011). It was noted that $13^{\text {th }}$ fraction had the maximum activity of $12.46 \mathrm{U} \mathrm{ml}^{-1}$ with $22.53 \mathrm{U} \mathrm{mg}^{-1}$ specific activity. Decreased protein contents $\left(0.553 \mathrm{mg} \mathrm{ml}^{-}\right.$ 1) indicated the reliability of this technique (Fig. 2, Table 1). Kelly and Reddy (1986) reported that after DEAE-sephadex treatment of $P$. chrysosporium glucose oxidase, $60 \%$ of the enzyme was recovered with 5.4-fold purification.

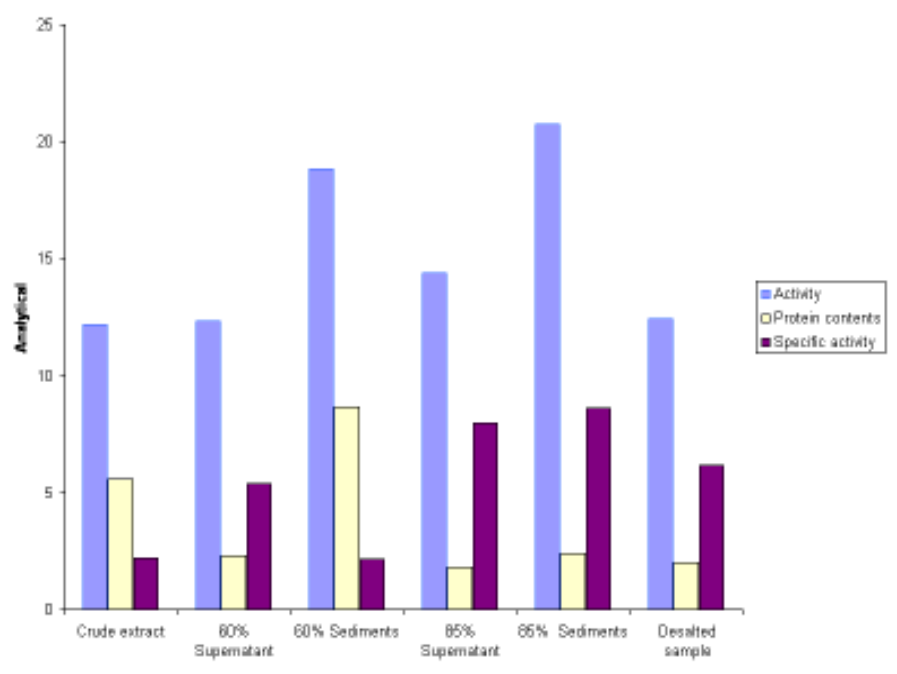

Figure 1 - Analysis of glucose oxidase activity in crude and after $\left(\mathrm{NH}_{4}\right)_{2} \mathrm{SO}_{4}$ precipitation. 


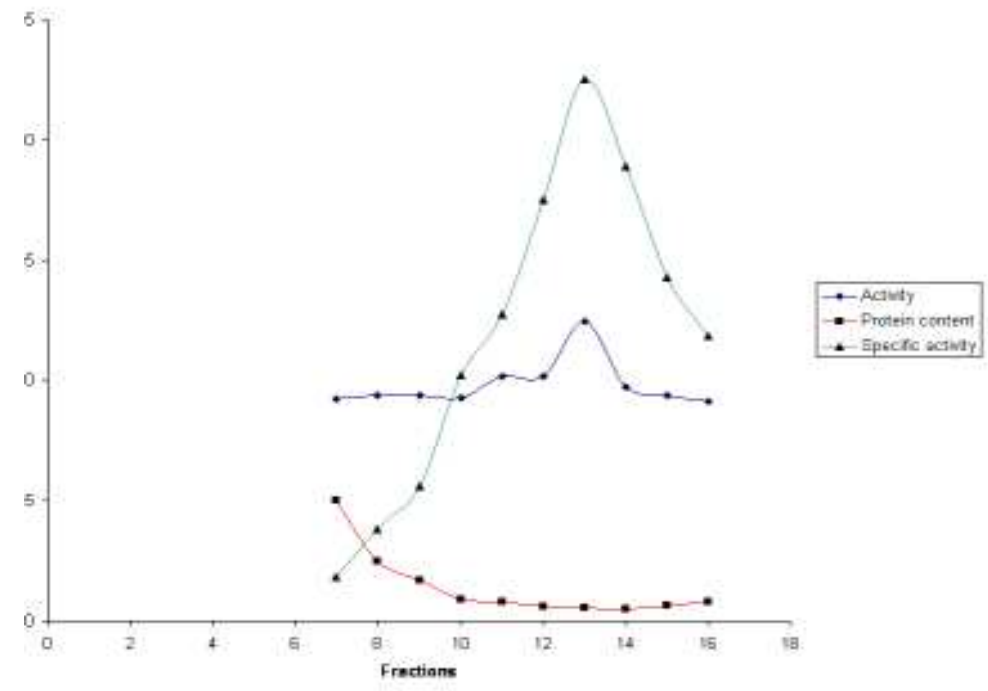

Figure 2 - Purification of glucose oxidase through ion exchange chromatography.

Table 1 - Purification summary of glucose oxidase enzyme.

\begin{tabular}{lccccc}
\hline \multicolumn{1}{c}{ Samples } & $\begin{array}{c}\text { Activity } \\
\left(\mathbf{U} \mathbf{~ m}^{-1}\right)\end{array}$ & $\begin{array}{c}\text { Protein contents } \\
\left(\mathbf{m g ~ m}^{-1}\right)\end{array}$ & $\begin{array}{c}\text { Specific activity } \\
\left(\mathbf{U} \mathbf{~ m g}^{-1}\right)\end{array}$ & $\begin{array}{c}\text { Fold } \\
\text { purification }\end{array}$ & $\begin{array}{c}\text { \% } \\
\text { Recovery }\end{array}$ \\
\hline $\begin{array}{l}\text { Crude } \\
\left(\mathrm{NH}_{4}\right)_{2} \mathrm{SO}_{4} \text { desalted }\end{array}$ & 12.195 & 5.562 & 2.192 & 1 & 100 \\
$\begin{array}{l}\text { After ion exchange } \\
\text { chromatography }\end{array}$ & 12.41 & 2.020 & 6.14 & 2.80 & 98.25 \\
$\begin{array}{l}\text { After gel filtration } \\
\text { chromatography }\end{array}$ & 12.46 & 0.553 & 22.53 & 10.27 & 97.83 \\
\hline
\end{tabular}

Gel filtration chromatography was applied by Sephadex G-200 which proved very efficient as the activity of 8th fraction was $18.94 \mathrm{U} \mathrm{mL}^{-1}$ while $59.37 \mathrm{U} \mathrm{mg}^{-1}$ was specific activity with 27.08 -fold purification (Fig. 3, Table 1). It was showed by
Kelley and Reddy (1986) that $P$. chrysosporium glucose oxidase produced 38-fold enrichment and $41 \%$ recovery of total activity. SDS-PAGE (12\%) and staining with coomassie brilliant blue G-250 showed the purity of glucose oxidase (Fig. 4).

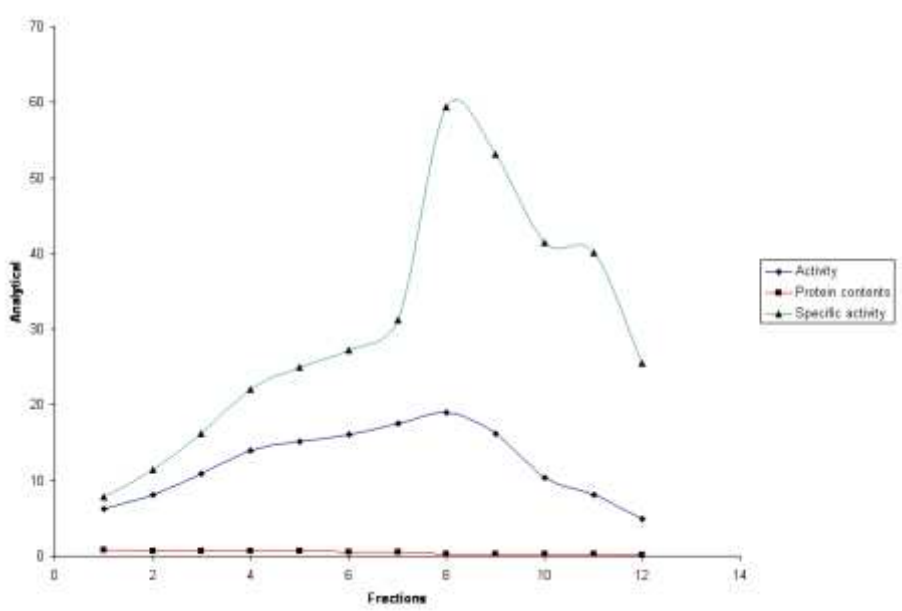

Figure 3 - Purification of glucose oxidase through gel filtration. 


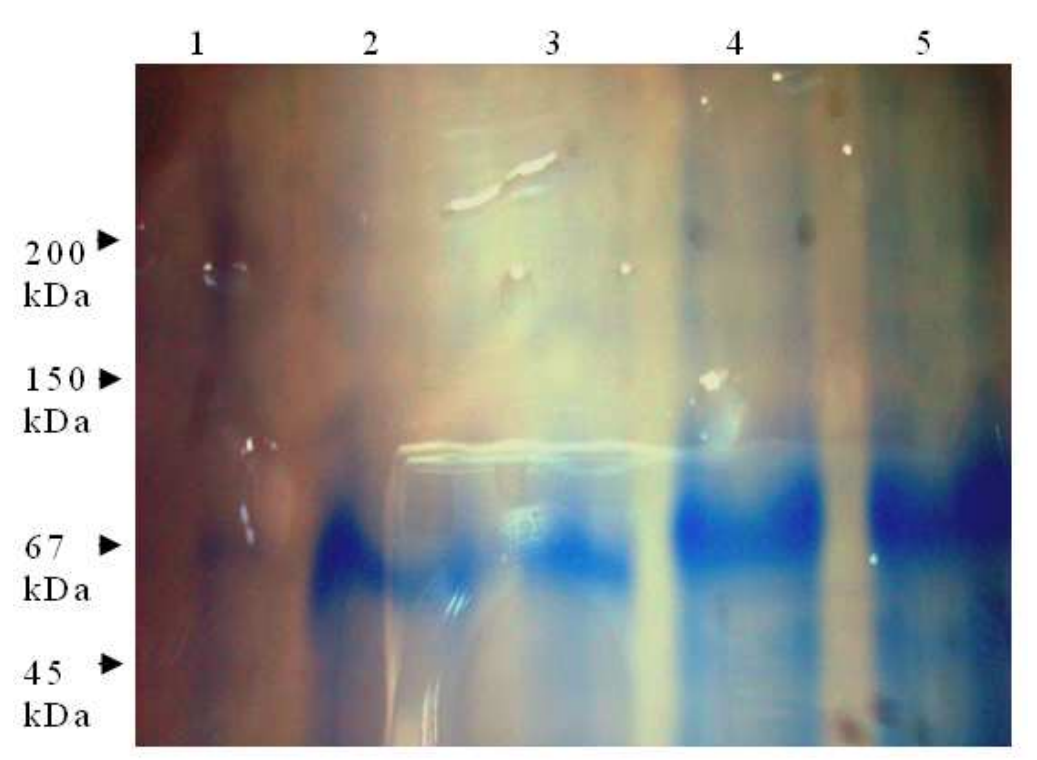

Figure 4 - SDS-PAGE of glucose oxidase (Lane 1 is markers and 2, 3, 4 and 5 are the replicates of enzyme obtained after gel filtration).

\section{Production of glucose oxidase antibodies}

The purified glucose oxidase was injected into rabbit to produce glucose oxidase antibodies. These glucose oxidase antibodies were confirmed by Agar Gel Precipitation Test (AGPT). The glucose oxidase antibodies were qualitatively measured/confirmed by agar gel precipitation test (AGPT/AGID) test (Hudson and Hay 1980). This test was used only to confirm whether the glucose oxidase antibodies were present or not in the serum of rabbit. The fine precipitation lines around the adjacent wells indicated a positive reaction and it confirmed the presence of anti- glucose oxidase antibodies. The good results of AGPT were obtained at $4^{\circ} \mathrm{C}$, not at room temperature in this work.

The distance between the central to peripheral wells is also an important factor. This test showed better results at $2 \mathrm{~cm}$ distance (Table 2).

Table 2 - AGPT results showing the presence of antibodies in experimental rabbit.

\begin{tabular}{lcccc}
\hline Sample & $\begin{array}{c}\text { Temp. } \\
(\mathbf{C})\end{array}$ & $\begin{array}{c}\text { Distance between } \\
\text { wells }(\mathbf{c m})\end{array}$ & $\begin{array}{c}\text { Distance between central and } \\
\text { peripheral wells }(\mathbf{c m})\end{array}$ & $\begin{array}{c}\text { Diameter of wells } \\
(\mathbf{m m})\end{array}$ \\
\hline Control & 4 & 1.75 & 2 & 4 \\
Experimental & 4 & 1.75 & 2 & 4 \\
\hline
\end{tabular}

\section{ACKNOWLEDGEMENT}

The present research work is the MSc thesis of Q.A. and was performed in EBL at University of Agriculture, Faisalabad. Authors are thankful to T.I. for SDS-PAGE and R.Z.A. for providing animal house facility.

\section{REFERENCES}

Banker SB, Bule MV, Singhal RS, Ananthanarayan L. Optimization of Aspergillus niger fermentation for the production of glucose oxidase. Food Bioproc Technol. 2009; 2(4): 344-352.

Gornall AG, Bardwill CJ, David MM. Determination of serum proteins by means of biuret reagent. J Biol Chem. 1949; 177(2): 751-766. 
Haq I, Ali S, Ashraf H, Qadeer MA, Rajoka MI. Mutation of Aspergillus niger for hyper-production of citric acid from black strap molasses. World $J$ Microbiol Biotechnol. 2001; 17(1): 35-7.

Hudson L, Hay FC. Practical Immunology. 2 edition. UK: Black well scientific publications; 1980. p. 1-9, 113-137, 227-229.

Jakoby WB. Methods in Enzymology. Vol. XXII. New York: Academic press; 1971.

Jiang T, Minunni M,Wilson P, Zhang J, Turner APF, Mascini M. Detection of TP53 mutation using a portable surface plasmon resonance DNA-based biosensor. Biosens Bioelectron. 2005; 20(10): 19391945.

Kalisz HM, Hecht HJ, Schomburg D, Schmid RD. Effects of carbohydrate depletion on the structure, stability and activity of glucose oxidase from Aspergillus niger. Biochem Biophys Acta. 1991; 80(2): 138-142.

Kelley RL, Reddy A. Purification and characterization of glucose oxidase from ligninolytic cultures of Phanerochaete chrysosporium. J Bacteriol. 1986; 166(1): 269-274.

Khattab AA, Bazaraa WA. Screening, mutagenesis and protoplast fusion of Aspergillus niger for the enhancement of extracellular glucose oxidase production. J Ind Microbiol Biotechnol. 2005; 32(7): 289-294.

Laemmli UK. Cleavage of structural proteins during the assembly of the head of bacteriophage T4. Nature. 1970; 277(5259): 680-685.

Luque R, Orejas M, Perottil NI, Ramon D, Luccal ME. $\mathrm{pH}$ control of the production of recombinant glucose oxidase in Aspergillus nidulans. J Appl Microbiol. 2004; 97(2): 332-7.

Scott D. Enzymes in Food Processing. 2nd ed. New York: Academic press; 1984.
Shin KS, Youn HD, Han YH, Kang SO, Hah YC. Purification and characterization of D-glucose oxidase from white-rot fungus Pleurotus ostreatus. Eur J Biochem. 1993; 215(3): 747-752.

Sukhacheva MV, Davydova ME, Netrusov AI. Production of Penicillium funiculosum 433 glucose oxidase and its properties. $J$ Appl Biochem. Microbiol. 2004: 40(1): 25-9.

Wijewardena TG. Haemorrhagic septicaemia. Rev Med Microbiol. 1992; 3: 59-63.

Witteveen FBC, van de Vondervoort P, Swart K, Visser J. Glucose oxidase overproducing and negative mutants of Aspergillus niger. Appl Microbiol Biotechnol. 1990; 33(6): 683-6.

Worthington CC. Worthington Enzyme Manual: Enzymes and Related Biochemicals. New York: Worthington Biochem. Coop; 1988.

Wu G, Shortt BJ, Lawrence EB, Levine EB, Fitzsimmons KC, Shah DM. Disease resistance conferred by expression of a gene encoding $\mathrm{H}_{2} \mathrm{O}_{2}$ generating glucose oxidase in transgenic potato plants. J Plant Cell. 1995; 7(9): 1357-1368.

Zia MA, Rehman K, Sheikh MA, Khan IA. Chemically treated strain improvement of Aspergillus niger for enhanced production of glucose oxidase. Int J Agr Biol. 2010; 12(6): 964-6.

Zia MA, Kousar M, Ahmed I, Iqbal HMN, Abbas RZ. Comparative study of peroxidase purification from apple and orange seeds. Afr J Biotechnol. 2011; 10(33): 6300-6303.

Received: May 24, 2010; Revised: December 28, 2010; Accepted: December 12, 2011. 